\title{
American Psychological Association
}

\author{
Honolulu, Hawai 'i, July 28-August 1, 2004
}

Located on the island of O'ahu- "gathering place" for the Hawaiians-the culturally diverse city of Honolulu is the setting for the 112th Convention of the American Psychological Association. Explore the local attractions-tropical gardens, sandy beaches, exotic mountain ranges, the Arizona Memorial at Pearl Harbor, the Bishop Museum, the Polynesian Cultural Center, Sea Life Park, the Nu'uanu Pali Lookout. Snorkel at Hanauma Bay, ride outrigger canoes, hike to Waimea Falls. Historic Kawaiaha'o Church and the nearby mission houses, 'Iolani Palace - the only royal residence in the United States and Queen Emma's Summer Palace-offer glimpses into Hawai' $i$ 's past. Sample the local cuisine-a mixture of the cuisines of China, Japan, Korea, the Philippines, Portugal, America, Southeast Asia; attend a luau featuring traditional Hawaiian food. In Honolulu the temperature in July hovers around $85^{\circ} \mathrm{F}\left(29^{\circ} \mathrm{C}\right)$. Leave your suits and ties at homeonly a few restaurants require jackets for men. Resort casual is acceptable dress everywhere. Get into the Aloha spirit!

oin the American Psychological Association (APA) for a different and unique annual convention! As with the last two conventions, most of the convention programming will be scheduled in one facility - the Hawai 'i Convention Center-near Waikiki. There will be a shorter day for substantive programming-8:00 a.m. to 2:00 p.m. - so attendees can participate in activities celebrating the diversity and attractions of the Islands. As a result of the shorter program day, the convention will be scheduled over five days, Wednesday through Sunday, rather than the usual four days. There will be three levels of programming: divisional programming, cross-divisional sessions developed by groups of divisions, and plenary sessions. In addition, there will be more opportunities for earning continuing education credits.

As stated in the association rules, the purposes of the annual convention are (a) to provide a forum in which members may present their scientific and scholarly work, (b) to present a general program that will be informative and of interest to all members of the association, (c) to facilitate the exchange of experience relating to the applications of psychology, and (d) to provide a place where the business of the association can be carried on efficiently.

Convention programs are developed by the several substantive divisions of APA and include symposia, paper and poster sessions, invited addresses, discussions, workshops, and so on. Meetings for the 112th convention are scheduled in the Hawai'i Convention Center, the Hilton Hawaiian Village Beach Resort and Spa, and the Sheraton Waikiki Hotel.

\section{Transportation}

Transportation from Honolulu International Airport is available by taxicab, airport express bus, and public transportation. The taxicab fare to the Waikiki area of Honolulu is approximately $\$ 25-\$ 28$ plus tip. The Airport Waikiki Express bus to any hotel in Waikiki operates 24 hours, leaves every 20 to 30 minutes, and costs $\$ 8$ one-way, $\$ 14$ round-trip. The trip takes about 20 minutes. Public transportation, TheBus, stops at the airport approximately every 30 minutes (Routes 19 and 20)-fare is $\$ 1.50$. For those renting cars in Honolulu, 24-hour guest parking at the APA headquarters hotels costs between $\$ 10$ and \$17.

Shuttle bus service will be provided during the convention between the Hawai' $i$ Convention Center and the Hilton Hawaiian Village Beach Resort and Spa and the Sheraton Waikiki Hotel.

Honolulu has an efficient bus public transportation system, TheBus, that has routes throughout the city and around the island. One-way fare is $\$ 1.75$. Visitors can purchase a Visitor Pass for $\$ 20$ for a four-consecutive-days pass and unlimited use at all ABC stores in Waikiki and at the Ala Moana Shopping Center (Web site: www.thebus .org).

Note: All prices listed above are subject to change.

\section{Airline Information}

APA has selected United Airlines and Delta Airlines as the official air carriers for the 2004 convention in Honolulu.

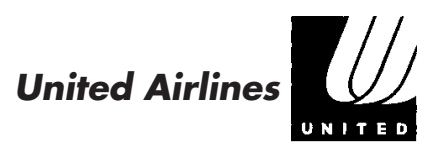

United Airlines is offering special discounts for the APA convention in Honolulu. You may choose a 5\% discount off any United or United Express published fare, including first class, or a $10 \%$ discount off the unrestricted midweek coach fare. As an extra bonus, an additional 5\% discount is 
available if you purchase your tickets at least 60 days in advance of travel. Or you may choose Area Pricing, a fixed airfare rate to the meeting based on geographical location. Area Pricing must be purchased at least 7 days in advance. These discounts apply on United Airlines and United Express flights. Reservations should be made as early as possible. Seats are limited. Restrictions may apply. Fares are guaranteed at the time of ticket purchase. Simply call or have your travel agent call United's toll-free number noted below for reservations and assistance.

\section{Continental United States and Canada}

United Airlines (daily, 8:00 a.m. to 10:00 p.m. Eastern time)

1-800-521-4041

Refer to Meeting Identification Number 597BD

\section{A.Delta AirLines}

Delta Air Lines is offering attendees a 5\% discount on the lowest applicable published airfares, or $10 \%$ off full-coach airfare. By purchasing your ticket 60 days or more prior to departure, you can receive an additional $5 \%$ bonus discount. There are also special fares between regional travel zones within the United States. The discounts apply only to travel in the continental United States, Hawai 'i, Alaska, Canada, Mexico, Bermuda, San Juan, Nassau, the U.S. Virgin Islands, and the Caribbean. To take advantage of these discounts, call or have your travel agent call the number noted below for reservations and assistance.

\section{Continental United States and Canada}

Delta Meeting Network Reservations (Monday-Sunday, 8:00 a.m. to 11:00 p.m. Eastern time)

1-800-241-6760

Refer to Delta File Number 200704A

\section{Classic Hawai'i Airfares and Outer Island Vacations}

APA has obtained the services of Classic Hawai' $i$, a custom vacation planner that offers discounted airfares to Hawai'i and assistance with planning vacations on the other islands of Hawai'i. Plan to spend a few extra days before or after the convention on the Valley Isle of Maui, the Garden Isle of Kaua' $i$, the Volcano Isle of Hawai' $i$, or the Pineapple Isle of Lana'i.

Classic Hawai'i offers you a choice of most scheduled carriers to Hawai'i, from more than 200 cities. You can save up to $40 \%$ off published airfares for economy and first-class tickets. Frequent flyer points are awarded with American, Continental, Delta, Hawaiian, and United. When making your reservation, be sure to ask for the lowest fare to Hawai' $i$ and the Change and Cancellation Waiver.

\section{Sample Roundtrip Airfares}

\section{Midweek Weekend States}

$\$ 781 \quad \$ 930 \quad$ Alabama, Florida, Georgia, Mississippi, North Carolina, South Carolina

$\$ 757 \quad \$ 907 \quad$ Connecticut, Delaware, District of Columbia, Maine, Maryland, Massachusetts, New Hampshire, New Jersey, New York, Pennsylvania, Rhode Island, Vermont, Virginia, West Virginia

$\$ 755 \quad \$ 904 \quad$ Illinois, Indiana, Iowa, Kansas, Kentucky, Michigan, Minnesota, Missouri, Nebraska, Ohio,

Tennessee, Wisconsin

$\$ 708 \quad \$ 856 \quad$ Arkansas, Louisiana, New Mexico, Oklahoma, Texas Colorado, Idaho, Montana, South Dakota, Utah, Wyoming Arizona, California, Nevada, Oregon, Washington

These fares provide a broad sampling for each area's major cities. There are exceptions within each area. Some exceptions will be lower, and some may be higher. The reservationists will have up-to-date fares at the time of inquiry. Here are few examples of exceptions:

$\begin{array}{lll}\text { Midweek } & \text { Weekend } & \begin{array}{l}\text { Exception Cit } \\ \$ 476\end{array} \\ \$ 571 & \begin{array}{l}\text { Los Angeles and } \\ \text { San Francisco } \\ \text { Atlanta }\end{array} \\ \$ 843 & \$ 875 & \end{array}$

Call NOW, the best airfares are going fast! 1-800-711-2491

Tell your reservationist how many people you will have in your party, your dates of travel, your departure city, and, if you are interested, the island you would like to visit for preor posttravel. It is quick, easy, and the best value anywhere! Be sure to mention you are attending the APA convention. Call Monday-Friday, between 6:00 a.m. and 6:00 p.m. Pacific time.

\section{Rental Cars}

APA convention attendees are urged to make arrangements for rental cars early! The summer months in Honolulu are popular, and demand for rental cars is high. Discounts are available to APA members and affiliates through Avis, Hertz, and Alamo. Be sure to ask for the lowest available rate for your preferred automobile.

\section{Avis}

Avis Rent a Car is offering special rates to all APA conference attendees. Call 1-800-331-1600 and mention AWD\# B774699 and AWD\# B774698 to check for the best rate available. Book online at www.avis.com; enter the number in the AWD\# prompt under the Rates and Discounts section. 
Hertz

Call 1-800-654-2200 or book online at www.hertz.com

APA/Hertz discount number: CDP 166639.

\author{
Alamo \\ Call 1-800-354-2322 or book online at www.alamo.com \\ APA/Alamo discount number: BY-93054.
}

\section{Convention Registration}

Register online on APA's Web site at www.apa.org/ convention. Convention attendees are urged to register for the meeting in advance. Advance registration not only assists APA in planning for the convention but also allows savings for the registrants. In addition, registration is required in order to enter the APA Exhibit Area.

Registration fees are required to support the costs associated with the convention, as well as to comply with the association's rule that the convention be a self-sustaining service of the association. Persons who request a replacement badge during the convention will be charged \$2 each time the request is made. Nonmember spouses/equivalents and dependents under age 18 may register by paying a nonrefundable processing fee of $\$ 10$ per person if their names appear on the registration form of a fee-paying registrant. The registration fees for the 2004 convention are as follows:

For those registering in advance (before June 21, 2004)

$\$ 185$ APA member, fellow, or associate; APA community college teacher affiliate; current international affiliate; new international affiliate (annual dues of \$27 included in registration)

$\$ 215$ Nonmember of APA

$\$ 60 \quad$ APA student affiliate

\$85 Full-time student; APA high school teacher affiliate

\$10 Nonrefundable processing fee for nonmember/nonpsychologist spouses/equivalents and dependents under age 18, if noted on the form of a fee-paying registrant

\section{For those registering on-site in Honolulu}

$\$ 240$ APA member, fellow, or associate;

APA community college teacher affiliate; current international affiliate; new international affiliate (annual dues of \$27 included in registration)

$\$ 270$ Nonmember of APA

$\$ 70 \quad$ APA student affiliate

$\$ 95$ Full-time student; APA high school teacher affiliate

$\$ 10$ Nonrefundable processing fee for nonmember/nonpsychologist spouses/equivalents and dependents under age 18, if noted on the form of a fee-paying registrant

The convention badge, with name and institutional affiliation, the Expocard, and the Convention Program will be mailed in advance of the convention to those who preregister. Advance registrants need only obtain a badge holder at the APA registration area in Honolulu to complete the procedure and thus avoid delays.

Complete registration facilities will be maintained at the Hawai'i Convention Center, Exhibit Hall, Level 1, according to the following schedule:

Tuesday, July 27
Wednesday, July 28
Thursday, July 29
Friday, July 30
Saturday, July 31
Sunday, August 1
3:00 p.m. to $8: 00$ p.m.
7:00 a.m. to $4: 00$ p.m.
7:30 a.m. to $2: 00$ p.m.
8:00 a.m. to $2: 00$ p.m.
8:00 a.m. to $2: 00$ p.m.
8:00 a.m. to $12: 00$ noon

Because of administrative delays, APA will not accept purchase orders for payment of convention registration fees.

Refund policy: Advance registrants who are unable to attend the convention may request a refund of their registration fee if a written request is received before August 1, 2004. A full refund of the registration fee will apply to requests received by June 21, 2004; a $75 \%$ refund will apply to requests received between June 22 and July 20, 2004; a 50\% refund will apply to requests received between July 21 and August 1, 2004. After August 1, 2004, no refunds will be issued.

\section{Housing}

\section{IMPORTANT!!!}

APA recognizes that you have a number of options when securing hotel accommodations for the annual convention. We would like you to understand that APA has made a major commitment to the city of Honolulu and to the hotel community in order to secure a large block of quality hotel rooms at competitive prices in convenient locations. APA is legally bound to fill these rooms. Not to do so has severe financial implications for APA and affects its negotiations and your costs for future conventions. If you require a hotel in Honolulu, we would appreciate it if you would review the list of APA hotels and reserve your room through the APA housing service, ITS.

Hotel reservations may be made DIRECTLY through the APA's housing service, ITS, by Internet, fax, mail, or phone. Only Advance Convention Registration Forms are to be sent to APA for processing.

In cooperation with APA, all of the APA hotels have set aside substantial blocks of rooms. These rooms for the convention are available only when reservations are made through ITS. To take advantage of the special APA room rates for the convention, be sure to book your reservations through ITS by July 6, 2004. After July 6, 2004, the official APA blocks will be released, and the hotels may charge significantly higher rates. Hotel rooms for persons arriving in the city at the last minute will probably be expensive, scarce, or nonexistent. We strongly recommend that you obtain hotel reservations early to ensure that you have a room at an APA hotel. 
During past conventions, the headquarters hotels have been filled by early May. It is anticipated that the headquarters hotels will also be filled early in Honolulu. Housing requests received toward the end of the advance registration period have typically been assigned alternate housing.

Registrants should bear in mind that rooms are assigned on a first-come, first-served basis. All rates are per room night and are subject to an $11.42 \%$ sales tax. Hotels will assign bedding preferences and other special requests at check-in. There is no guarantee that persons will obtain a room in the specific hotel they have requested, in the type of room requested, or at the rate requested. If accommodations are not available at the hotel of your choice, comparable reservations will be made at other contracted hotels.

Please note that the availability of rooms for those arriving before July 28 may be limited. Therefore, if you are attending preconvention activities, ITS will make every effort to accommodate your needs but cannot guarantee rooms for those with early arrival dates.

Reservations can be made through ITS by Internet, telephone, fax, or mail beginning on November 14, 2003. Requests received after July 6, 2004, will be processed on a space-available basis. Beginning July 15, 2004, all reservations must be made directly with the hotels. To reserve a room for the APA convention, choose ONE of the following methods:

Internet: Fill out the Hotel Reservation Form and use the interactive Web site at www.apa.org/convention/ to submit the form directly;

or

Telephone: Call ITS, Monday-Friday, 8:00 a.m. to 5:00 p.m. (Central time) at (800) 974-9833 (toll free) or (847) 282-2529 (international). Phone reservations are limited to five per call;

or

Fax: Send a completed Hotel Reservation Form, using one form per reservation request, to (800) 521-6017 or (847) 940-2386;

$$
\text { or }
$$

Mail: Send a completed Hotel Reservation Form, using one form per reservation request, to ITS, 108 Wilmot Road, P.O. Box 825, Deerfield, IL 60015-0825. All hotels require a guarantee with each reservation request. Hotel Reservation Forms received without a credit card for the required guarantee will not be processed. No checks or wire transfers will be accepted for the guarantee.

ITS will send you a confirmation. Review it carefully for accuracy. Room confirmation will be sent only to the primary person requesting the reservation. If you do not receive a confirmation by e-mail, fax, or mail within 14 days of sending your request, please contact ITS at www.ampsy@itsmeetings.com or call (800) 974-9833 or (847) 282-2529.
All hotels require a guarantee with each reservation request. Requests received without a credit card for the required guarantee will not be processed. Please fill out the credit card information in its entirety. Credit cards must be valid through August 2004 to be processed and considered a proper guarantee. Guarantees can be made by providing an American Express, VISA, MasterCard, Discover, or Diners Club credit card number on your Hotel Reservation Form. Beginning July 8, 2004, hotels will CHARGE this card in the amount of the first night's room and tax, per reservation.

Persons sharing a room are requested to send in only one Hotel Reservation Form with the names of all of the proposed occupants of the room. By law, there is a limit of four persons to a room, and some hotels will not accept reservations for four persons in a room. Room confirmation will be sent only to the person requesting the reservation. Colleagues wishing to stay in the same hotel should submit their forms in the same envelope.

Changes and Cancellations: Changes or cancellations made on or before July 12, 2004, should be made directly with ITS. After July 15, 2004, you must contact your confirmed hotel directly. Deposits are fully refundable for cancellations received prior to 72 hours of arrival. Deposits will be forfeited for cancellations made within 72 hours of scheduled arrival.

\section{Headquarters Hotels and Rates}

Note: Rates are per night for either single or double occupancy and do not include $11.42 \%$ tax. Add third-person rate for each additional person. Parking rates are subject to change without notice.

Hilton Hawaiian Village Beach Resort and Spa (1,400 rooms): Large self-contained resort with five towersRainbow Tower, Tapa Tower, Diamond Head Tower, Kalia Tower, and the exclusive Ali 'i Tower-offering garden/ mountain or ocean views. Three swimming pools, white sand beach, health club and spa, over 90 shops in the Rainbow Bazaar and Ali'i Tower Plaza. Children's program for ages 5 to 12 years in the Rainbow Express Keiki Club. Green/environmentally friendly hotel. No charge for children 18 years old and under when they use existing bedding in the same room as their parent(s) or grandparent(s). Twenty-four-hour guest parking (valet \$17; selfpark \$12). Twelve-minute walk to Convention Center; APA shuttle bus to Center.

Note: Division and APA events will be scheduled at the Hilton Hawaiian Village Beach Resort and Spa.

Rates: Garden/Mountain View: \$185; Ocean View: \$210; Ali'i Garden/Mountain/Ocean View: \$285; Third Person: \$45; Suites: \$500 and up.

Sheraton Waikiki Hotel (700 rooms): Large modern convention hotel on Waikiki Beach and on Kalakaua Avenue, the main thoroughfare through Waikiki. Rooms offer mountain or ocean views. Two swimming pools, fitness center. Keiki Aloha Club for children ages 5 to 12 years. No charge for children under 18 years old when they 
use existing bedding in the same room as their parent(s). Twenty-four-hour guest parking (valet \$15; self-park \$10). Twenty-five-minute walk; 10 -minute cab ride to Convention Center; APA shuttle bus to Center.

Note: APA Continuing Education Workshops in Psychology will be held at the Sheraton Waikiki Hotel.

Rates: City/Mountain View: \$179; Ocean View: \$199; Third Person: \$50.

\section{Supplemental Hotels and Rates}

Ala Moana Hotel (450 rooms): First-class hotel across the street from the Hawai'i Convention Center, across from Ala Moana Beach Park and adjacent to the Ala Moana Shopping Center. Swimming pool, fitness center. No charge for children under 18 years old when they use existing bedding in the same room as their parent(s). Twentyfour-hour guest parking (valet \$12; self-park \$9).

Rates: Standard room with two double beds and city, mountain, or ocean view in Waikiki Tower: \$139; Deluxe room with one king or two double beds on Torch Ginger Floors (top 7 floors) and mountain or ocean view: \$159; Third Person: \$25.

Hawai'i Prince Hotel Waikiki (200 rooms): Deluxe hotel at the gateway to Waikiki near the Ali Wai Yacht Harbor. All rooms offer ocean views. Swimming pool, fitness center, access to 27-hole Hawai 'i Prince Golf Club designed by Arnold Palmer. No charge for children under 17 years old when they use existing bedding in the same room as their parent(s). Twenty-four-hour guest parking (valet $\$ 16$; self-park \$11). Seven- to 10-minute walk to Convention Center.

Rates: \$164; Third Person: \$40.

Ohana Maile Sky Court Hotel (300 rooms): High-rise moderate hotel located at entry to Waikiki near the Hawai' $i$ Convention Center-managing company identified as finalist for Healthy Workplace Award, sponsored by the Hawai'i Psychological Association. Rooms are simply furnished, not large, but are clean and well-maintained and offer views of the city or ocean on the higher floors; kitchenettes available. No charge for children under 18 years old when they use existing bedding in the same room as their parent(s). Swimming pool, coin-operated laundry room, access to Cowabunga Kids Club at the Outrigger Reef Hotel. Twenty-four-hour guest parking (\$8). Tenminute walk to Convention Center.

Rates: Standard: \$78; Kitchenette: \$88; Third Person: \$20.

Renaissance Ilikai Waikiki Hotel (280 rooms): Recently renovated deluxe hotel overlooking the Ali Wai Yacht Harbor. Spacious rooms, most with ocean views; studio rooms with fully equipped kitchen and bath with shower only are available. No charge for children under 17 years old when they use existing bedding in the same room as their parent(s). Laundry room facilities. Two swimming pools, tennis court, fitness center. Twenty-four-hour guest parking (valet $\$ 18$; self-park \$14). Seven- to 10-minute walk to Convention Center.

Rates: \$165; Kitchen Studio Room: \$195; Deluxe Ocean View Room: \$195; Third Person: \$30.

The Royal Hawaiian Hotel (50 rooms): Historic luxury hotel, "Pink Palace of the Pacific"-located on Waikiki Beach, a quiet oasis behind the Royal Hawaiian Shopping Center on Kalakaua Avenue-historic building and highrise tower. Swimming pool, access to fitness center at Sheraton Waikiki Hotel. No charge for children under 17 years old when they use existing bedding in the same room as their parent(s), one child per paying adult, maximum two children per room. Twenty-four-hour guest parking (valet $\$ 15$; self-park \$10). Twenty-five-minute walk or 10-minute cab ride to Convention Center; access to APA shuttle bus at Sheraton Waikiki Hotel.

Rates: Historic Garden View: \$215; Historic Ocean View/Tower: \$285; Third Person: \$75.

\section{Arrangements for Persons With Disabilities}

The APA Council of Representatives has adopted "Guidelines on Physical and Social Accessibility," prepared by the APA Task Force on Psychology and the Handicapped. In compliance with these guidelines, the Board of Convention Affairs asks each person with a disability who is planning to attend the convention to identify himself or herself and to provide information on how APA can make the convention more accessible for him or her. Please check the appropriate box on the Advance Convention Registration and Hotel Reservation forms if you are disabled and would like assistance in facilitating your attendance at the convention. A note outlining your specific needs should accompany the Advance Convention Registration and Hotel Reservation forms. APA will provide a van with a lift as transportation for persons who use wheelchairs, interpreters for hearing-impaired individuals, and escorts/readers for persons with visual impairments if specific requests are provided at the time of advance registration. During the convention, persons with disabilities who desire a place to relax or who desire assistance with wheelchair repairs, readers, escorts, interpreters, and so on may visit the APA Resource Room for Persons With Disabilities.

To facilitate hotel reservations for those who need wheelchair accessibility and visual or hearing aids, the Board of Convention Affairs has compiled information about the headquarters hotels. It is strongly suggested that persons who are in need of wheelchair-accessible accommodations request housing at one of the following hotels. Additional information regarding accessibility of supplemental hotels and a detailed report on accessibility of headquarters facilities may be obtained from the APA Convention Office in Washington, DC.

Hawai'i State Animal Quarantine Laws: Hawai' $i$ is a rabies-free state. Importation of dogs, cats, and other carnivores into Hawai' $i$ is governed by a law that requires a 120-day confinement in the State Animal Quarantine Station. The law allows exemptions to quarantine confine- 
ment for guide and certified service dogs. Go to the Web site at www.hawaiiag.org/hdoa/ai_aqs_guidedog.htm for requirements and further information.

\section{Hilton Hawaiian Village Beach Resort and Spa \\ Main Entrance: Accessible}

Public restrooms: Most of the restrooms are accessible, but please note the following challenges. Mid-Pacific Conference Center: The men's and women's restrooms on the sixth floor next to Coral Ballroom 1 are difficult for someone who uses a scooter because the turning radius is tight. Kalia Tower: At the time the accessibility compliance study was done there were no grab bars in the single-stall men's room or the women's accessible stall next to the pool and Mandara Spa. There are very good accessible restrooms next to the cafe on the lobby level of this building. Braille signage: Braille signage is on guestroom doors and elevators.

Sleeping rooms: 45 rooms are designed for wheelchair accessibility, and 30 of them have roll-in showers; 45 additional rooms have been modified to accommodate guests with hearing and visual impairments.

Meeting rooms: In the Mid-Pacific Conference Center, the only elevator between the Coral Ballroom and Nautilus Suite on the sixth floor and the South Pacific Ballroom and Sea Pearl Suite on the mezzanine level is a service elevator, requiring guests to go through a service corridor to reach those meeting rooms.

Restaurants: Accessible

Aids: Assisted listening devices including TTDs (Telecommunications Device for the Deaf) are available upon request. Shower benches are available upon request. Electrical outlets are at pay phones for TDDs.

Note: A Hilton Hawaiian Village Accessible Rooms Fact Sheet is available upon request by contacting the APA Convention Office at (202) 336-6020 or by e-mail: convention@apa.org.

\section{Sheraton Waikiki Hotel \\ Main entrance: Accessible \\ Public Restrooms: Accessible}

Braille signage: Braille signage on guest room doors and elevators.

Sleeping rooms: 15 rooms are designed for wheelchair accessibility; 9 rooms and one large suite with roll-in showers.

Meeting rooms: Accessible

Restaurants: Accessible

Aids: Assisted listening device kits and TTDs are available upon request. Shower benches available upon request.

Rooms designed for wheelchair accessibility are also available at the Ala Moana Hotel, the Hawai' $i$ Prince Hotel Waikiki, the Ohana Maile Sky Court Hotel, the Renaissance Ilikai Waikiki Hotel, and the Royal Hawaiian Hotel.

APA secured the services of Paul Sheriff Incorporated to conduct a roll-through of all convention headquarters fa- cilities and produce a written report on accessibility and ADA compliance. Copies of this report will be made available upon request.

\section{Employer Exhibit Booths}

Job opportunities for attendees can be found in the APA Exhibit Hall. Employer exhibit booths will be located in a section of the APA exhibits in the Exhibit Hall, Level 1, Hawai 'i Convention Center. Employers who are interested in obtaining a booth may request information from Ms. Jodi Ashcraft, Exhibits Manager, American Psychological Association, 750 First Street, NE, Washington, DC 200024242 (202-336-5565).

\section{Child Care}

For financial reasons, APA will not be providing on-site facilities for a children's hospitality center in Honolulu. Parents who require child care during the convention may make arrangements with existing child-care services in Honolulu. Although APA is providing names of resources that are located in Honolulu, APA is not endorsing these companies or liable for services provided by them. There are additional companies to which hotels refer guests who require child care. Parents may call directly to make arrangements in advance.

Note: The Hilton Hawaiian Village Beach Resort and Spa and the Sheraton Waikiki Hotel offer programs for children staying at these hotels. Details may be obtained by contacting these hotels directly.

Sitters Unlimited of Hawai'i, P.O. Box 88505, Honolulu, HI 96830-8505; phone: 808-674-8440; fax: 808-674-8441; E-mail: sittersunlimited@ sittershawaii .com. Rates (four-hour minimum): One child- $\$ 12$ per hour; two children $-\$ 15$ per hour; three children $-\$ 20$ per hour; four children- $\$ 25$ per hour plus tax. If services are canceled within 24 hours prior to scheduled start time, the fee is $\$ 30$. In addition, a transportation fee may be applicable.

Kama'aina Kids: While you are in meetings, Kama'aina Kids will provide your children with a complete "Children's Aloha Program" including activities that are safe, educational, and fun. Children will enjoy age-appropriate Hawaiian-style "must-see" excursions, including Sea Life Park, Hawaiian Waters Adventure Park, Bishop Museum, Kualoa Ranch, and Waikiki Aquarium, and enjoy culturally enriching experiences. Kama 'aina Kids' trained and certified staff will care for children 5-17-years-old in an 8 to 1 ratio. The approximate cost is $\$ 65.00$ per day. This includes lunch, transportation, and entrance fees. If you are interested in having your child participate in the Children's Aloha Program, please call Kathy Hew, Vice President Hotel \& Convention Services, toll free at 1-888345-4374 or e-mail kathy@kamaainakids.com by May 30, 2004. For more information about Kama'aina Kids, visit their Web site: www.kamaainakids.com 


\section{Continuing Education in Psychology Workshops}

Continuing Education in Psychology Workshops, designed to offer a broad array of continuing education topics for practitioners and scientists, will be offered during the convention at the Sheraton Waikiki Hotel. Sponsored by the APA Continuing Professional Education Committee, the workshops are designed to upgrade the skills and knowledge of clinicians, academics, and those in research. Participants earn continuing education credits for these workshops. All workshops are scheduled for either a half day (four hours) or a full day (seven hours). Complete information about the activities offered and an enrollment form will be in a special tear-out booklet in the April 2004 issue of the APA Monitor on Psychology. Call the Continuing Education in Psychology Office at (800) 374-2721, extension 5991, if you have any questions.

\section{Convention Personnel}

You may wish to contact one or more of the following persons before or during the convention:

Chair, Board of Convention Affairs: Michael L. Haley, c/o Convention Office, American Psychological Association, 750 First Street, NE, Washington, DC 20002-4242.

Director, Convention/Meetings: Candy Won, American Psychological Association, 750 First Street, NE, Washington, DC 20002-4242. (202) 336-6020.

Continuing Education in Psychology Program: Brennan Harmuth, Continuing Education in Psychology Office, American Psychological Association, 750 First Street, NE, Washington, DC 20002-4242. (202) 336-5991.

\section{Convention Program Availability}

The Convention Program will be mailed only to advance registrants and individuals who specifically request a program. Individuals who are not planning to attend the convention but who would like to receive a Convention Program should complete the mailing label found elsewhere in this section. Programs will be available in early July, after the advance registration deadline of June 21. Convention preregistrants should bring their copies of the program to the convention. There will be a charge of $\$ 5$ for additional copies of the program. Our supply of programs in Honolulu will be limited. If you are uncertain about whether you will attend the convention, please see highlights of the program in the April to June 2004 issues of the APA Monitor on Psychology.

\section{Mailing Label for the Convention Program}

If you will definitely not attend the convention and would like to order a copy of the Convention Program, please fill out the label below and return it to the Convention Office, American Psychological Association, 750 First Street, NE, Washington, DC 20002-4242. Your program will be mailed in mid- to late July. Advance registrants and on-site registrants will automatically receive copies.

\section{Print Only-Zip Code Is Imperative}

Name

Mailing Address

City

State _ Zip Code 


\section{Advance Registration Instructions}

Fill out the form on the facing page. Print legibly, entering information in the space allowed. Each individual attending convention activities must register using a separate form. For housing, fill out the Hotel Reservation Form found elsewhere in this section. Send the Advance Convention Registration Form no later than June 21, 2004, to APA 2004 Convention, P.O. Box 630303, Baltimore, MD 21263-0303. You can also register online on APA's Web site at http://www.apa.org/convention.

1. Name: Enter last name, first name, middle initial. Tiłle: (Dr., Mr., Mrs.) —optional.

2. Institution: Enter your affiliation (e.g., Yale Univ., private practice, Sunset CMHC).

3. City, State or Province, and Country: Enter the city, state or province, and country (if not the United States) of your institution for your badge.

4. Mailing Address: Two lines are allowed for the mailing address. If it is necessary to designate a department, use the first of these two lines. (This address will be used to mail your badge and Convention Program in July.) Street address will facilitate delivery.

5. City, State or Province, Zip or Postal Code: Use standard post office abbreviations for the state or province.

6. Country: If you are not a resident of the United States, enter the name of your country.

7. Telephone Number: Please provide your daytime telephone number, including area code.

8. APA Member Number: Please provide your APA membership number.

9. E-mail Address: Please provide your e-mail address.

10. Registration Fee: Enter fee paid. Payment (check or credit card) for registration fee must accompany form. For those paying by VISA MasterCard, or American Express, please complete the Credit Card Payment Authorization Form on the bottom of your Advance Convention Registration Form.

\$185-APA Member, Fellow, Associate; APA Community College Teacher Affiliate; current International Affiliate; new International Affiliate (annual dues of $\$ 27$ included in registration)

\$215-Nonmember of APA

$\$ 60$-APA Student Affiliate

\$85-Full-Time Student; APA High School Teacher Affiliate

\$10 - Nonrefundable Processing Fee for Nonmember/Nonpsychologist Spouses/Equivalents, Dependents Under Age 18 (see No. 16 below)

11. Membership Code: From the list below, select your membership status code; enter it in the space allowed.
M-APA Member
H-APA High School Teacher Affiliate
Q-State/Provincial Association
Y-APA Community College Teacher Affiliate
F-APA Fellow
$\mathrm{N}$-Nonmember
S-APA Student Affiliate
A-APA Associate
$\mathrm{R}$-Current International Affiliate
$\mathrm{T}$-Full-Time Student Representative
$\mathrm{X}$-New International Affiliate

12. Primary Division: If you are not a division member, leave this area blank. If you are a member of only one division, enter the division number (see list below) in this space. If you are a member of more than one division, enter the division number of your primary division membership here. This information is used in allocating program hours to divisions.

13. Other Divisions: If you are a member of more than one division and have listed your primary division in No. 12 above, list your remaining division memberships in order of most important to least important. List no more than six such memberships.

List of divisions for Questions 12 and 13:

1-General, 2-Teaching, 3-Experimental, 5-Evaluation, Measurement, and Statistics, 6-Behavioral Neuroscience and Comparative, 7-Developmental, 8-Personality and Social, 9-SPSSI, 10-Psychology of Aesthetics, Creativity, and the Arts, 12-Clinical, 13Consulting, 14-Industrial and Organizational, 15-Educational, 16-School, 17-Counseling, 18-Public Service, 19-Military, 20-Adult Development and Aging, 21-Applied Experimental and Engineering, 22-Rehabilitation, 23-Consumer, 24-Theoretical and Philosophical, 25-Behavior Analysis, 26- History of Psychology, 27-Community, 28-Psychopharmacology and Substance Abuse, 29-Psychotherapy, 30-Psychological Hypnosis, 31-State Psychological Association Affairs, 32-Humanistic, 33-Mental Retardation and Developmental Disabilities, 34-Population and Environmental, 35-Psychology of Women, 36-Psychology of Religion, 37-Child, Youth, and Family Services, 38-Health Psychology, 39-Psychoanalysis, 40-Clinical Neuropsychology, 41-Psychology-Law, 42-Psychologists in Independent Practice, 43-Family Psychology, 44-Lesbian, Gay, and Bisexual Issues, 45-Ethnic Minority Issues, 46-Media Psychology, 47Exercise and Sport, 48-Peace Psychology, 49-Group Psychology and Group Psychotherapy, 50-Addictions, 51-Men and Masculinity, 52-International Psychology, 53-Clinical Child and Adolescent Psychology, 54-Pediatric Psychology, 55-Pharmacotherapy.

14. Instifutional Code: Enter one of the following numbers to identify the type of institution to which you belong:

1-Universities, Colleges, and Professional Schools, 2-Primary and Secondary Schools (Public and Private), 3 - Government (Federal, State/Provincial, or Local), includes all military services, 4-Business/Industry, 5-Nongovernmental Organizations (Associations or QuasiGovernmental or International Organizations), 6-Human (Mental/Health) Services (Hospitals, Clinics, CMHCs, or Independent Practice), 7-Other Professional (Non-Mental/Health) Services (Research Organizations, etc.), 8—Other (Retired/Emeritus, Self-Employed Individual/ Owner, except Independent Practice, etc.).

15. Persons With Disabilities: If you are a person, with a disability and require special assistance, check this box. Attach a separate note specifying special needs (e.g., van for wheelchair).

16. Nonmember Nonpsychologisł Spouse/Equivalent or Dependent(s) Under Age 18 Registration: If you wish to register a nonmember nonpsychologist spouse/equivalent or dependent(s) under 18 years of age, please provide name(s) for badge information. Nonmember nonpsychologist spouse/equivalent and dependent(s) under age 18 are exempt from paying a registration fee if their names appear in this space on a fee-paying registrant's form. A $\$ 10$ per person nonrefundable processing fee will be required.

17. City, State or Province, and Country: Please provide your city, state or province, and country (if not the United States) for badges of nonmember nonpsychologist spouse/equivalent and dependent(s) under age 18.

18. Total Fees Due: Enter total fees due. Payment must accompany form for your registration to be processed.

19. Return the Advance Convention Registration Form to the APA 2004 Convention, P.O. Box 630303, Baltimore, MD $21263-0303$. Advance Convention Registration Form will be returned by APA if not accompanied by a check or the Credit Card Payment Authorization Form for the registration fee. Checks must be payable in U.S. dollars and drawn on a U.S. bank. 
Fill out the Hotel Reservation Form for room reservations.
American Psychological Association

2004 Convention $\bullet$ Honolulu, Hawai'i $\bullet$ July 28 -August 1, 2004

Advance Convention Registration Form

1. Name:
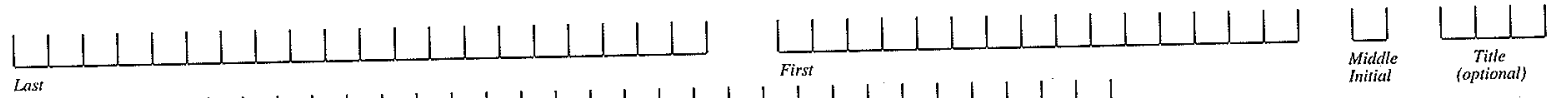

2. Institution:

3. City: Domat ereed 30 characters, including spaces. Will appear on badge.

State/Province:

Country (if not U.S.):

4. Mailing Address:

Zip/Postal Code:

6. Country (if not U.S.):

7. Telephone Number:

B. APA Member Number:

9. E-mail Address:

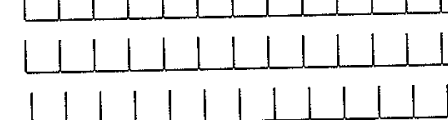

State/Province:

10. Registration Fee:

11. Membership Code:

12. Primary Division:

(Primary division is used for allocating program hours to divisions.)

14. Other Divisions:

14. Institutional Code:

16. Person With Disability: (Leave blank if not disabled)

16. Name(s) of Nonmember Nonpsychologist Spouse/Equivalent or Dependent(s) Under Age 18:

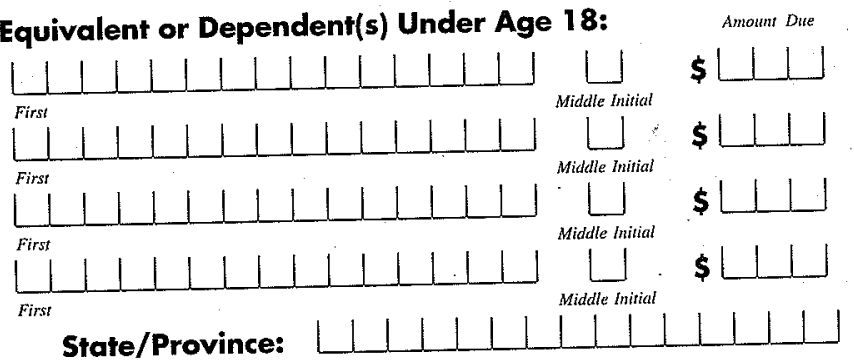

1) elity

(a)

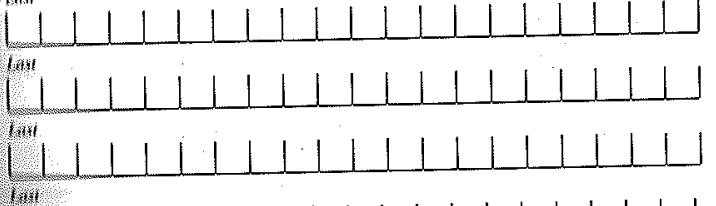

Ceuntry (if not U.S.):

11. Tial Fees Due (Payment must accompany form): $\quad \$ L \perp$

1. Wivin Form With Accompanying Check (in U.S. dollars/U.S. bank) or with a completed Credit Card Payment Wharization Form to: APA 2004 Convention, P.O. Box 630303, Baltimore, MD 21263-0303. DEADLINE: June 21, 2004.

\section{Credit Card Payment Authorization Form}

Min the American Psychological Association to charge my

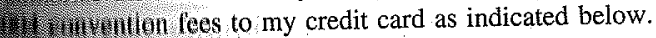

กลmai

311) W T Cardholder:

W Torl Number:

Thin Date:
Circle One: VISA MasterCard American Express

Fee to Be Charged: \$ (convention registration)

Daytime Phone Number:

Name of Registrant:

Cardholder Signature:

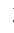




\section{American Psychological Association \\ 2004 Convention $\bullet$ Honolulu, Hawai' $i$ - July 28-August 1, 2004 \\ HOTEL RESERVATION FORM}

\section{INSTRUCTIONS}

Hotel reservations can be made through ITS by INTERNET, FAX, PHONE, OR MAIL between November 14, 2003, and July 6, 2004. All requests will be processed on a space-available basis. To reserve a room for the APA convention choose ONE of the following methods:

INTERNET: Fill out the form and submit it directly by using the interactive Web site at www .apa.org/convention, or

TELEPHONE: Call ITS, Monday-Friday, 8:00 a.m.-5:00 p.m. CST at (800) 974-9833 (toll free) or (847) $282-2529$ (international), or

FAX: Send a completed housing form, one copy per request, to (800) 521-6017 or (847) 940-2386, or

MAIL: Send a completed housing form to ITS, 108 Wilmot Road, P.O. Box 825, Deerfield, IL 60015-0825.

\section{CONFIRMATIONS}

ITS will send you a confirmation. Review it carefully for accuracy. If you do not receive a confirmation via e-mail, fax, or mail within 14 days after sending your request, please contact the housing bureau at ampsy@itsmeetings.com, (800) 9749833, or (847) 282-2529.

\section{ROOM RATES/TAXES}

To take advantage of the special APA convention rates, be sure to book your reservation by July 6 , 2004. After July 6, 2004, the official APA blocks will be released, and the hotels may charge significantly higher rates. All rates are per room night and are subject to tax (subject to change). Some hotels may charge additional fees for rooms with more than two occupants. When making a reservation, please provide room and bedding preferences in the "Special needs" line on the form. The hotels will assign specific room types at check-in, on the basis of availability.

\section{GUARANTEE}

All hotels require a guarantee with each reservation request. Requests received without credit card information for the required guarantee will not be processed. Please fill out the credit card information entirely. Credit cards must be valid through August 2004 to be processed and considered a proper guarantee. No checks, money orders, or wire transfers will be accepted. Beginning July 8 , hotel will charge this card for first night's room and tax. No checks, money orders, or wire transfers will be accepted.

CHANGES/CANCELLATIONS

Changes/cancellations made on or before July 12 , 2004 , should be made directly with ITS. After July 15,2004 , you must contact your confirmed hotel directly. Deposits are fully refundable for cancellations received prior to 72 hours of arrival. Deposits will be forfeited for cancellations made within 72 hours of scheduled arrival.

\section{Housing for the APA convention opened on November 14, 2003}

\section{Send Confirmation to:}

First Name Last Name MI

E-mail Address

Daytime Phone Fax

(If number is not within the U.S., please provide the ENTIRE number needed to reach you from the United States.)

Company/Institution (if applicable)

Address

City/State/Province Zip or Postal Code/Country

\section{Hotel Information:}

Arrival Date Departure Date

Hotel Selection: (List three choices in order of preference.)

First Second Third Reservations will be processed on a first-come, first-served basis. If all three requested hotels are unavailable, please process this reservation according to: comparable room rate proximity to conference site do not book if unavailable

Room Type:

No. of people to occupy room No. of beds requested in room

List all room occupants:

Nonsmoking room requested

Special needs

Wheelchair-accessible room required

Required Guarantee Information (credit cards will be charged beginning July 8 for first night's room and tax):

By Credit Card Only

Type of Card:
American Express Discover
MasterCard Diners Club
VISA
Account Number Expiration Date

Name of Cardholder 


\section{Honolulu, Hawai'i (Waikiki)}

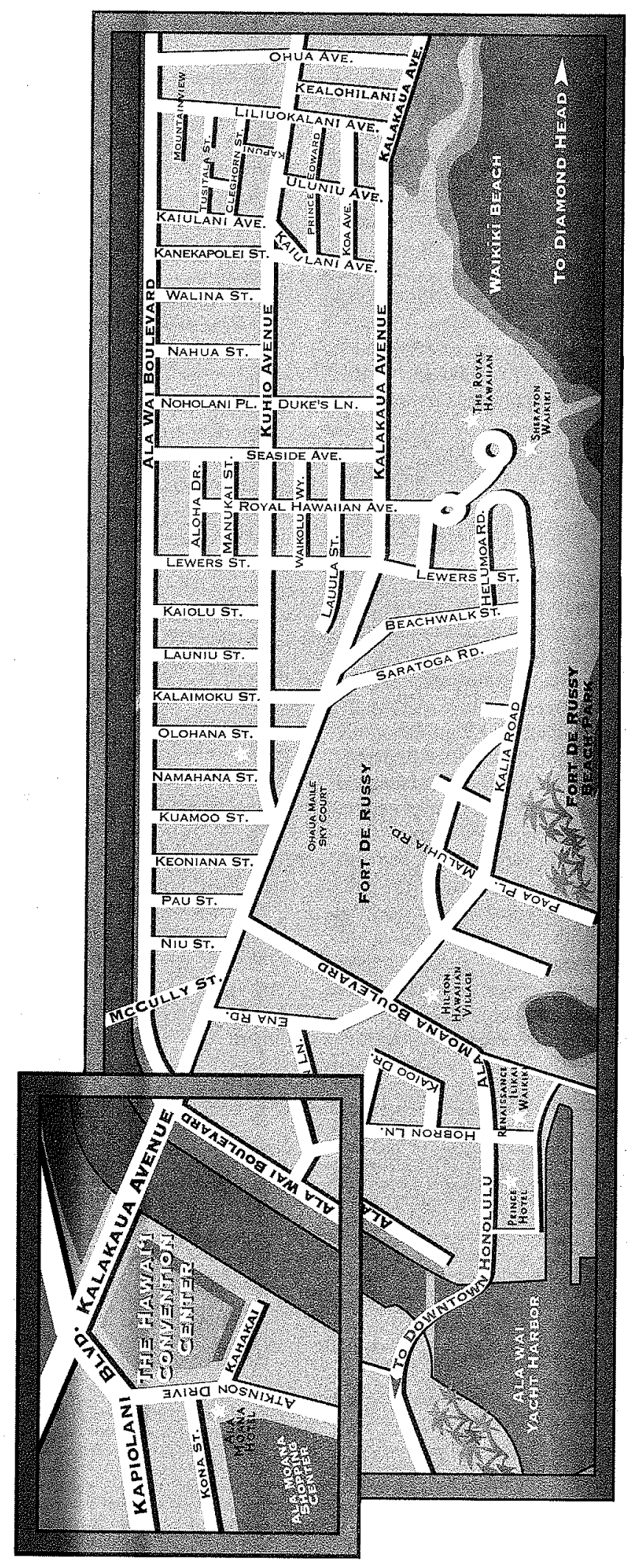

